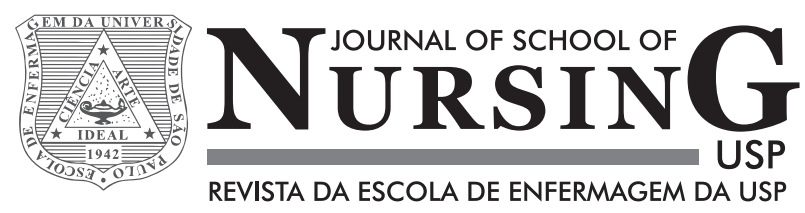

\title{
Development of premature children: caregivers' understanding according to the Bioecological Theory
}

\author{
Desenvolvimento de crianças nascidas prematuras: a compreensão \\ dos cuidadores à luz da Teoria Bioecológica \\ Desarrollo de niños nacidos prematuros: la comprensión de \\ los cuidadores a la luz de la Teoría Bioecológica
}

Rayla Amaral Lemos ${ }^{1}$, Maria de La Ó Ramallo Veríssimo ${ }^{2}$

${ }^{1}$ Universidade de São Paulo, Escola de

Enfermagem, Programa de Pós-Graduação em Enfermagem, São Paulo, SP, Brazil.

${ }^{2}$ Universidade de São Paulo, Escola de Enfermagem, Departamento de Enfermagem Materno-Infantil e Psiquiátrica, São Paulo, SP, Brazil.

\begin{abstract}
Objective: Understanding the conceptions of premature children caregivers on child development and associated factors. Method: An exploratory-descriptive qualitative study of 12 families with children under three years of age. Interviews were submitted to thematic content analysis, systematized into the categories of Bioecological Theory of Human Development: Process, Person, Context and Time, and in the Functional Development category. Results: There are concerns about impairment in the current and future development of a Person/child defined as fragile as a result of premature birth (Time dimension), minimized by the scope of observable competencies such as motor skills. The Context, especially family and health services, and Proximal Processes, described as one-way caregiver interactions, are considered determinants of development. Functional Development is considered a natural consequence and result of education. The support network is crucial, supporting or limiting care. Conclusion: Concerns about the development mobilize caregivers to stimulate the premature child/person and requests family and healthcare assistance.
\end{abstract}

\section{DESCRIPTORS}

Child Development; Infant, Premature; Caregivers; Family; Pediatric Nursing.

\section{Corresponding author:}

Rayla Amaral Lemos

Av. Dr. Enéas de Carvalho Aguiar, 419 -

Cerqueira César

CEP 05403-000 - São Paulo, SP, Brazil

raylalemos@usp.br
Received: 12/07/2014

Approved: 08/20/2015 


\section{INTRODUCTION}

Child care varies according to the understanding of the development and the factors related to it. This is even more evident in situations that potentially interfere with development, such as premature birth, a condition that impacts child development ${ }^{(1-4)}$. Frequently, it influences how caregivers deal with the children, due to their own feelings of fear and insecurity generated by this situation ${ }^{(5-6)}$.

Studies have characterized the peculiarities of preterm infant development ${ }^{(1-3)}$ as complications suffered early ${ }^{(7-8)}$, and at later ages ${ }^{(9-12)}$, showing losses or damages in various dimensions. However, they have focused the assessment of deficits on abilities and behaviors in specific areas such as speech, motor function, or school learning through standardized tests. Although they have contributed to characterize the development of this population and the effects of prematurity, thereby supporting the (re)thinking of caring for children born prematurely, they have a limited contribution to understanding the functional development. Functional development refers to the skills and independence for activities of daily living and to perform their social role ${ }^{(4)}$. Functionality allows for continuity of autonomous, independent and active development in society and throughout life, even under limitations.

Another major shortcoming is the fact that most studies do not address caregivers' understanding about the development of their children, nor on the attitudes of care for promoting it. Healthcare professionals' lack of knowledge about the understanding of caregivers reduces their ability to satisfactorily respond to their demands, and to some extent, can foster more insecurities and anxieties ${ }^{(13)}$. As family and community are the developmental contexts in which the child participates most and spends most of their time, caregivers should be considered partners in promoting child development ${ }^{(13)}$. This opens up a new horizon of research to achieve less costly and more effective strategies to improve the health, quality of life and development of children born prematurely.

The objective of this study was to understand family caregivers of premature infants' conceptions on child development and the factors associated with it.

\section{THEORETICAL FRAMEWORK}

The framework that guided the study was Urie Bronfenbrenner's Bioecological Theory of Human Development ${ }^{(14-15)}$, which postulates development as a process of stability and changes of individuals' biopsychological characteristics, throughout the course of life and across generations, with these being dependent and rooted in four interactive dimensions: Process, Person, Context and Time ("PPCT Model")(14-15).

Process refers to the reciprocal interactions between the subject and the people, objects and symbols of their immediate environment, in gradual levels of complexity. Regular interactions and for a long period of time constitute the proximal processes, which affect the expression of genetic potential and can create positive or negative effects on development, depending on the personal characteristics and the environment interactions ${ }^{(14-15)}$.
An active Person interacts with the environment in their development, according to their biopsychosocial features. The personal attributes have three areas: the demands that elicit responses from others to the person in development, such as curiosity, gender and skin color; the resources, either cognitive and emotional, such as ability and intelligence or social and material, such as housing and parental support; and the disposition/strength, to engage and persist in activities of progressive complexity ${ }^{(14-15)}$.

Context encompasses any event or condition outside the body, which potentially influences or is influenced by the developing being; it is organized in a four-level hierarchy of progressively broader systems ${ }^{(14-15)}$ : Microsystem, or the primary context of development, of face to face interactions, like the home, day care, school; Mesosystem, or bonds and processes between microsystems in which the developing person is inserted, such as the relationship between the family and school; Exosystem, or set of contexts that influence the development of the person, even if they are not inserted in them, such as work place of parents; Macrosystem, or culture, beliefs, values, ideology; global standards; social, political and economic systems.

Time is the structure that captures a changing environment, "the degree of stability or changes in the lives of individuals in the face of environmental events and transitions that occur throughout life, producing conditions that affect the development of the people" ${ }^{(15)}$. It is divided into microtime, mesotime and macrotime. Microtime refers to continuous and non-continuous events in proximal processes; mesotime is the amount of repetition of these events during the days and weeks; and macrotime is related to changes and transgenerational episodes, and more broadly to society. So the Time encompasses change and stability of individual and group human development, throughout the course of life and across generations in history ${ }^{(16)}$.

\section{METHOD}

An exploratory and descriptive qualitative study approved by the Research Ethics Committee of the Universidade de São Paulo School of Nursing (number 447.725). It was carried out in the Follow-up clinic for newborns at risk, Department of Child and Adolescent Health of the City of Juiz de Fora, Minas Gerais, in April and May 2014. This clinic receives, evaluates and monitors the development of children who were discharged from the Neonatal Intensive Care Units of the city and region.

Family caregivers of children under 3 years of age born with any level of prematurity were invited to participate in the research while awaiting a follow-up visit in the waiting room of the service; thus constituting a convenience sample. Inclusion criteria were to be the primary caregiver of the child and the children had no diagnosis of serious neurological, orthopedic or respiratory disease, or an atypical development classification. Immediately after the invitation, the explanation of the research objectives, and signing the Informed Consent Form, the interviews were conducted in a private office at the site, and recorded with the consent of the participants. 
Open semi-structured interviews lasting an average of 30 minutes were conducted by a single previously trained researcher, until the empirical categories were saturated. The interview guide was designed based on the literature review and the objective of the research. It was independently and jointly revised by two researchers, and then evaluated by a group of researchers for suggestions and adjustments. The themes that comprised the guide were: the caregiver's concepts on the development of their child; factors that can promote or hinder development; stimulation strategies used; questions or concerns on the subject; knowledge of functional development as part of child development. Functional development was introduced during the interview by presenting illustrations of children performing functional abilities of self-care, mobility and social function, and by asking participants about these behaviors as part of child development.

The characterization of the population included age, marital status and educational level of the primary caregiver and family socioeconomic status, according to the Brazilian Economic Classification Criterion ${ }^{(17)}$. Gestational age, birth weight and the current age of the children were also identified to characterize the experiences of caregivers. Throughout the study, the analyses of interviews were submitted to a group of researchers who evaluated the quality and conduction of the process and verified them as appropriate during the study.

Interviews were transcribed and analyzed according to the content thematic analysis ${ }^{(18)}$ and to the Bioecological Theory of Human Development ${ }^{(14)}$. They were identified as E1 to E12. The empirical categories of analysis were preset according to the "PPCT Model," since it represents a broad view of the development concept and favors a comprehensive analysis which is adequate to the research proposal. Therefore, it will allow for proposals of future actions of promoting development, by way of interventions in the proximal processes and context. The Functional Development category was also established by the specific interest of this study.

\section{RESULTS}

There were twelve interviews conducted with eleven mothers and one grandmother; three mothers were accompanied by their partners. The age of the caregivers varied between 19 and 53 years; most (eight) had only one child. As for the children, gestational ages ranged from 28 to 36 weeks; birth weight ranged from 1000 to $2220 \mathrm{~g}$; in relation to the present age, the youngest child was five months and the oldest 25 , with more than $80 \%$ of participants under the age of two. All had few complications at birth; six participants remained hospitalized for weight gain for less than 30 days. According to Table 1, most caregivers were married, with secondary education or higher and belonged to classes B and C.

Participants showed interest in reporting their experiences and knowledge, although initially they did not seem to be clear about what the term development meant. In the presentation of the categories there are excerpts from some interviews, aiming to demonstrate the results more thoroughly.
Table 1 - Descriptive characteristics of the study population Juiz de Fora, MG, Brazil, 2014.

\begin{tabular}{|c|c|c|c|}
\hline Characteristics & & $* * \mathrm{~F}(12)$ & $\%$ \\
\hline Caregiver marital status & $\begin{array}{l}\text { Married } \\
\text { Not married }\end{array}$ & $\begin{array}{l}9 \\
3\end{array}$ & $\begin{array}{l}75.0 \\
25.0\end{array}$ \\
\hline \multirow{4}{*}{$\begin{array}{l}\text { Caregiver education } \\
\text { level }\end{array}$} & $\begin{array}{l}\text { Incomplete primary } \\
\text { education }\end{array}$ & 3 & 25.0 \\
\hline & $\begin{array}{l}\text { Incomplete secondary } \\
\text { education }\end{array}$ & 2 & 16.7 \\
\hline & $\begin{array}{l}\text { Complete secondary } \\
\text { education }\end{array}$ & 6 & 50.0 \\
\hline & $\begin{array}{l}\text { Complete higher } \\
\text { education }\end{array}$ & 1 & 8.3 \\
\hline \multirow{5}{*}{$\begin{array}{l}\text { Socioeconomic } \\
\text { Classification* }\end{array}$} & B2 & 4 & 33.3 \\
\hline & C1 & 1 & 8.3 \\
\hline & $\mathrm{C} 2$ & 3 & 25.0 \\
\hline & $\mathrm{D}$ & 2 & 16.7 \\
\hline & Not reported & 2 & 16.7 \\
\hline
\end{tabular}

Legend: *Brazilian Economic Classification Criterion 2012, According to Brazilian Association of Companies and Research (ABEP); ${ }^{* *} \mathrm{~F}$ : absolute frequency.

The Process category appeared as a central focus of development and encompassed actions or situations that can positively influence or generate negative effects on child development. Such actions or situations constitute proximal processes as they relate to direct interactions with the child, and they were described by interviewees as a result of their actions toward the child in a unidirectional way.

Many aspects present in daily practice at home are perceived by caregivers as child development enhancers and attitudes of care as: continuous affection and participative presence of caregivers (E1, E3, E5, E6, E7, E8, E10), stimulation and teaching children skills, especially motor skills (E1, E2, E4, E5, E7, E8, E11); providing games, toys and conversations (E3, E4, E5, E6, E7, E8, E9, E10, E11); reading, music or sports (E4, E5, E6, E8, E9, E11); offering healthy foods (E2, E7); and socializing with other children at home, in the neighborhood, or in day care (E6, E7, E10). Characteristics that underlie the proximal processes are observed in these contents, which refer to mutual interaction with people, objects, and symbols in a continuous manner over long periods of time, and people with whom the child has a positive relationship of affection.

\section{I give them the utmost attention I can, I sit down, $I$ watch $D V D$ s with them, I sing them songs (...) we play with cars (...) with dolls, we play house (E6). \\ I encourage her to walk, I put her on the floor with support, she slowly finds her way up. I en- courage her to eat a lot of things too, like fruit, healthy things, so she can have a good healthy development (E7).}

I'm already starting to teach her to put things away, such as when she plays. I lay her on the floor and put her toys far away for her to get them (E2).

We help a lot with the development... Through love, affection, and also teaching, educating (E5). 
I think that reading and music can help, also sports, letting him free to play in the dirt, flying kites, running, instead of being stuck indoors, playing video games all day, no. Freedom for him to run, to play ... barefoot, kick a ball and maybe hurt his toes (...). Playing during bath time... he already knows the song to take off his clothes; he knows that he is getting a bath (E9).

As for the influence of negative factors in the development Process, they highlight: the mistreatment and lack of affection or tenderness of caregivers (E1, E3, E6, E10, E11); too many expectations and pressure on the development trajectory (E7); restrictive care to the independence of the child (E9); speech or negative influence from people nearby or external to their coexistence (E1, E5, E7, E9).

Mistreating, not taking proper care. I think it must be highly disruptive to the child. Not receiving any affection (E1).

Too much confusion in the house... I think it leaves children disoriented (E10).

We think that the child has to develop at that time, to grow up quickly, to develop, but (the other person), no! (E7).

The discourse and the interference of others are mentioned as possible causes to limiting development (E1, E5, $\mathrm{E} 7, \mathrm{E} 9)$, as they influence the caregiver, generating changes in child care, modifying the proximal processes.

Everyone kept telling me that a premature infant of eight months does not survive, and if they survive, they take time to develop ... because she was born prematurely, I was thinking she was very fragile, that something could happen anything at any time. (...) There are certain things that you hear, so it stays in your mind, so it bothers you in your day to day, and makes you worried (E7).

As for the category Person, premature birth defines a child's demand, because it creates expectations and concerns about their development. We can observe the presence of two perceptions, both linked to the Person attributes: satisfactory development, and unsatisfactory or inadequate development. For both of them the demand of prematurity is the mediating characteristic in the classification that they make to the development in the past, present or future. Gradually, caregivers will get to know the child and understand their resources and disposition; also they associate these resources and disposition to the development they observe in the child, which shows recognition of the child's own role in its development. Parents value acquisitions, mainly motor skills, and attribute them to the child, characteristics such as intelligence, astuteness and ability to learn fast that seem to supplant the prematurity condition (E1, E3, E4, E5, E6, E7, E8, E9, E10, E11, E12).

\footnotetext{
She is very smart ... very curious ... she learns very easily... she picks thing up very fast. Everything you say to her she'll remember that too (E3).
}

Each day he comes with something new, learning something (...) He already turns on the television, turns on the radio, if I blink he's playing on my cellphone (...). He's really pretty smart (E10).

Weight gain and growth are seen as development progress, meaning that if the weight gain characteristic is present, the child is doing well (E1, E2, E3, E7, E8, E9, E12).

We were worried about the weight because she was born 1,700 grams (1.7 kg), but she put on weight fast. Now she's 8.05 kilos and she's almost walking, her teeth came out fast too. It is a fast development for a child of 8 months (E7).

Concerns regarding the biological characteristic of premature birth and its influence on current or future development of the child were especially apparent related to motor skills (E1, E2, E3, E4, E6, E7, E8, E9, E11, E12). It was possible to recognize their beliefs by the way they characterized their children and their current development, as well as their fears and feelings about their future. The caregivers described them as small or fragile, and shared recent or past concerns, such as fear of delays, deficiencies, and even the fear of the child not surviving. Therefore, the understanding that prematurity as a specific characteristic of the Person shall take effect on the development in the short to medium term emerges, and brings forth the dimension of Time.
I thought it would take her longer to walk (...) because she was born so premature, if in the future that will have any consequences to her. (...). Today, I think she is developing alright, but in the future will it delay her? It could be in her coordination/motor skills, her little head, something (E4).

\section{To this day I'm insecure, I'm afraid, you know, to lose him (E3).}

Overprotective behaviors are observed as a result of changes in attitudes of care in the proximal processes due to concerns about development of a premature child (E4, $\mathrm{E} 7, \mathrm{E} 11)$. In this way, a relationship is defined between the Person and Process dimensions.

I get very fussy about her (...). To protect her. Everything is very clean, I don't like that she puts things in her mouth (...). I do not know if this is good for her, this overprotection (E4).

In the Context category, the four systems of hierarchical levels of Bioecological Theory were clearly recognized in the conceptions of the factors that can promote or hinder child development. Microsystems appear strongly in the narratives, highlighting how much conflicting contexts and homes without a spouse can be harmful (E3, E6), and how much other microsystems such as childcare and health services can be promoters of development (E1, E2, E3, E4, E7, E8, E11).
(...) what is harmful ... in my street, for ex- ample, there are many children there, who live with their mothers and do not have a father in 
their life (...) they really act out on other children with anger, hitting them (E6).

In day care she learns many different things, each day she learns something new ... to stand up alone, playing on the table, she learns to eat new things... she laughs more (E7).

Dr. P. is very good. We are very blessed. When I brought her here the first time, she was tiny, it was difficult to handle her... God has blessed me, she is great (E1).

The Mesosystem appears in the relationship between family and health services where children are cared for. When this relationship is positive, caregivers perceive an equally positive influence on development (E4, E7, E10, E11); on the contrary, when this relationship shows negative aspects, they conclude that it creates an unfavorable environment for child development (E9, E11).

People who work at the health clinic do home vis-
itations (...) they have come many times. They
came, put him up on his feet to see how he was
going to take steps... They talked to me a lot too,
explaining everything to me (E10).

If you do not trust the doctors, there is no point in bringing them here, in wanting the children to develop quickly, it won't happen (...) I'd rather come when he's here/working, I have more confidence (E7).

The follow-up was supposed to be done in January, he was only seen in March ... we were worried about everything (...) when he was discharged from the maternity ward, they didn't prescribe anything (...). He said that he was going to prescribe a priest; that it was a case of praying. That was when didn't trust him anymore. We asked to be transferred here. In SD (the neighboring town) the doctor is great, but she cares for everyone the same way. If they are premature, if they aren't, if they're handicapped, if they aren't. There is no specific care like here, you know? (E9).

It is worth mentioning that this context of child development works like a Proximal Process for caregivers. The relationship between the family and the service produces knowledge and support to the extent that they feel they are or are not instructed on how to care for the child. In the absence of such support, either from inadequacy of professionals or delay in specialized care, a negative experience with health care institutions is established.

The presence of family and friends as a support network is also valued as being effective for the provision of child care, in that it reinforces the mother on their needs and anxieties (E7, E9).

Family support is very important for children to have a good development... All my needs, all my doubts (...) my mother is always there helping me (E7).
The Exosystem emerges when referring to the neighborhood or to areas of collective use that could be harmful to the child's development due to lack of living spaces and especially violence and drug trafficking in public spaces (E3, $\mathrm{E} 4, \mathrm{E} 9)$.

Regarding the municipal government and stuff, the plazas/playgrounds need to receive better care (...). For us to have somewhere to take them to have fun, to be comfortable. A nice place she likes, where she can play (...) to develop. There are some places where you cannot even go with children, so many drugs (...). You get scared to even go out of the house with the children (E3).

The Macrosystem appears in two ways: as awareness of the influence it produces, and as global conjecture of the organization of society, manifested by the lack of public policies for social welfare, culture and recreation, and urban violence (E9, E10).

We live in a system (...) There are issues of education, health, security, I have hope that the future will be great for him. But... the city does not give me conditions, nor an opportunity to improve his life, of having a good future (E9).

In the Time category, the data show the understanding that each child has their own learning and development pace in time, by changes throughout their life. So caregivers attribute the significance of progress by the pace with which learning/ and skills are acquired. Despite this, they understand that these patterns of change and stability can be more specific for a premature child, who may present particularities in the continuity of their development, such as delays in acquiring skills and independence when compared to a normal standard (E1, E3, E5, E6, E7, E8).

She has developed since 3 and a half months (...).
She doesn't even seem like a premature child (...)
people say that premature children develop faster.
Honestly (E5).
She walked at 1 year and 6 months and she's
slowly starting to speak, saying Dad, Mom, call-
ing Grandma, her brother, and she is counting.
She can count from 1 to 4 . On top of that, she's
developing bit by bit (E6).

As for the Functional Development, respondents believed that the reach of functional abilities is part of the child's overall development. However, they argue that such capabilities will happen over time, as a natural process in the course of development (E7, E8). The Time dimension can also be seen here as well, in light of the Bioecological Theory. In contrast, despite putting these acquisitions on the nature of the continuities and changes in development, they maintain that they need to be taught, or learned by imitation, eliciting a valuation of proximal processes as precursors of these functional skills (E1, E2, E5, E7, E8, E9, E10, E11, E12).

All these activities are things that at some point they will learn ... having their independence 
to drink things with their own hands, eating things with their own hands, putting on clothes, taking clothes off, these are phases. Over time they will happen ... Oh, teaching... I put the cup in her hand, the bottle, she already knows ... If you do not teach them, then the child will not learn alone. (...) By teaching they will eventually learn. It will take time, but they will learn (E7).

It is also worth pointing out the key questions and issues of interest to caregivers: premature child development, premature birth and/or high-risk pregnancy, nutrition, exams the child needs to do, positioning and ways of holding the child, the most common illnesses in premature infants, and getting to know the experience of other caregivers.

\section{DISCUSSION}

The results provide evidence for an understanding of human development based on the PPCT model, with the specificities of the premature child. The prematurity condition is placed in the discussion as a characteristic of the person/child in Time which influences the development not only because of itself but also by the care provided. Care for premature children has a complexity that covers the Proximal Processes and Contexts; furthermore, it is related to the characteristics of all the participants in the relationships.

Descriptive characteristics of the population show a group of children with low and moderate risk to experience damage in their development, because the mean weight and gestational age showed no extreme values and the amount of neonatal complications were small. In addition to this there was the presence of protective factors, such as caregivers mostly with partners, with higher education, and absence of extreme poverty, meaning intermediate socioeconomic levels ${ }^{(19-21)}$. Both conditions together possibly reflects positively in the care and development of children, which can be seen in the positive way in which caregivers perceive this process. So in accordance with the Bioecological Theory, there are positive characteristics of the Person/child and the Microsystem interacting synergistically, affecting the proximal processes and promoting their development.

In addition, the systematic monitoring that they get from health services can be one of the factors that justify caregivers classifying their children as developing well. Monitoring development is widely recognized and underlined by the Health Systems ${ }^{(22-23)}$ and confirmed by the proposals in the Bioecological theory in relation to the microsystem $^{(14)}$. The data show the recognition of the effect of the family support network and health assistance, aspects of the mesosystem and exosystem, to promote development ${ }^{(24-25)}$. This reaffirms the close relationship of "an appropriate combination of formal and informal relationships capable of providing support, guidance and assistance in the difficult task of caring for and educating children"(18). Also, this points to healthcare and political implications, as it stresses the importance of specific services and the actions they perform as a support network ${ }^{(24-25)}$.
The support of health services is even more relevant for caregivers of a premature child, given the influence of other members of the community who end up expressing concerns possibly due to prejudice or ignorance. Many external forces over which caregivers have no control may affect the proximal processes ${ }^{(19)}$, as was the case in this study: caregivers decisions about the care they provided for children could be influenced by people nearby when they were not very sure about what to do. Then, healthcare services have a guiding and systematizing care role while the family has a more supportive character in the daily care ${ }^{(25)}$. In addition, the results of this study corroborate another ${ }^{(13)}$, showing that caregivers desire information about the child's current health status and future implications, highlighting the need and service of professionals to share knowledge and create strategies for their involvement and participation.

The Process, as in Bioecological Theory, appeared as a central focus. A prevalence of recognizing unidirectional actions towards the caregiver for the child was noted in the description of the favorable and unfavorable factors for development. Thus, there appeared to be an understanding that child development is a product of the care offered by the family. Participants highlighted the lasting relationships permeated by strong emotional attachment as motivators of the child engaging in more complex activities of their context; they understand that when these relationships are conflicting and the offered care is of low quality, development can be compromised, with the appearance of behavioral problems, learning problems at school, and socialization difficulties, among others, as highlighted by the literature ${ }^{(14,19)}$.

This unidirectional perspective is also evident in how caregivers perceive the Person/premature child, such as when they are perceived as fragile, leading to a view that development should be supported. The prematurity attribute, such as the child's demand, had an important effect on the proximal process, thus affecting care. The expectations of caregivers in the way they care for and stimulate the child's development may vary depending on the demands, resources and the disposition that they see in the children. The literature confirms that overprotective attitudes of caregivers in the care of premature children is a result of this perception of the child's fragility ${ }^{(16)}$. Finding this result in a population with access to specialized service incites questions about the educational strategies that could minimize the distress of caregivers. Prematurity can still limit the participation of the child, because the perception of weakness may be regarded as a lack of resources for their engagement in activities and may even restrict the mother-child interaction, as pointed out in another study ${ }^{(5)}$, consequently affecting their development.

On the other hand, the identification of other demands and resources of the Person/child, such as intelligence and a good pace of learning, refers to the active participation of children in their development, and highlights the domains of resources and disposition/strength. This triggers stimulating attitudes that will allow the progressive involvement of children in more complex activities ${ }^{(14)}$, generating a virtuous circle of promoting development. It is worth 
mentioning that to be in the situation of caring for a premature child may have influenced the Process dimension in the development of the caregivers, stimulating a closer look, which enables them to more effectively check the child's developmental achievements.

The concern of caregivers about their child's motor skills and weight gain as pictures of progress or delays in development should also be highlighted. This concern leads them to promote the achievement of these characteristics, which generates a resource of good development for the Person/ child. On the other hand, the perception of focused development on these observable aspects provokes reflection on other dimensions of development that can be overlooked and recognizes the need of addressing this issue with caregivers.

The variation of proximal processes according to the Context particularly emerged in understanding of the microsystem as the main niche of promotion or loss of development, highlighted as damaging situations of mistreatment and violence in the home, corroborating data from other studies in light of this Theory ${ }^{(19)}$. In addition, the reported scarcity and insufficiency of cultural services, leisure, social protection and social assistance brings forth many implications in this context, stressing the responsibility of society for child development. Services and management need to be sensitive to these demands, not only as a legal right, but as an investment in human development.

The Time dimension has a particular character in this study, given the clarity of its expression by the participants (caregivers of premature children). Time is more than an influential dimension, it is inherent in the development of premature children; the child is a function of time. Gestation time is crucial; the less gestation time, the higher the chances of negative effects ${ }^{(7)}$ for life and development, and even survival of the child. Due to the performance of the Time dimension, the child is already born with specific demands, resources and strengths, meaning, the prematurity condition has caused changes in the processes, in the context and in the person himself. The course of the premature child's development will be influenced by this condition over time. The need for following-up, the perception of deadlines for the realization of achievements, potential delays, and expectations about the future, are all examples of the performance of this dimension. Thus, the perspective of caregivers is focused on microtime and mesotime, in that their understanding has been built on individual experience and from observing the child himself. Understanding the development of premature infants as a group in the transgenerational environment of macrotime does not appear in the results, which is expected since this approach is a more specific focus of researchers and scholars of the Theory.

As for the Functional Development category, it is important to reflect that it is the development of functional capabilities that allows the child to be, and to be in his Context as a Person, through the Processes established along their development path in Time, reaching independence, social participation and autonomy. The data show dichotomy, given the understanding of functional skills as naturally occurring event in the course of life, but also as the fruition of the teaching and example that the child imitates. These results are corroborated by the literature that highlight the functional performance of the preschool child as influenced by established Processes in early childhood ${ }^{(4,19)}$.

The demands of parental knowledge show that the development of their premature children is an issue that mobilizes them. A lack of knowledge can generate anxieties and attitudes of care not always conducive to development, therefore this subject should be focused on healthcare interventions and on educational materials.

As one limitation of this study, we can mention the convenience sample of a group accompanied by a specialized service in following the at-risk children, therefore it may be more oriented towards child development compared to others who live in the same condition and do not have access to this service.

\section{CONCLUSION}

This study expands the knowledge of premature infant's caregivers on child development, favoring more targeted and systematic actions to develop promotion strategies and illness prevention, and providing protective contexts. Prematurity, as a Person's condition in Time, generates important effects on interactions with caregivers, which in turn stimulate the child's functional development by examples and teaching, although considered it as naturally resulting from Time. Caregivers promote development with protection of the family and the healthcare support network, but still require clarification and support to act as promoters of child development, including information on this process. These tasks are the responsibility of the community, healthcare assistance, management and public policy.

The Bioecological Theory of Human Development has proved to be an important framework for analysis and interpretation of data, providing increased knowledge and identification of knowledge on caregivers, relating to the influences of Process, Person, Context and Time on the development of premature children.

\section{RESUMO}

Objetivo: Compreender as concepções de cuidadores de nascidos prematuros sobre o desenvolvimento infantil e fatores associados. Método: Estudo exploratório-descritivo, qualitativo, com 12 famílias de menores de três anos de idade. Entrevistas submetidas à análise temática de conteúdo, sistematizados nas categorias da Teoria Bioecológica do Desenvolvimento Humano: Processo, Pessoa, Contexto e Tempo, e na categoria Desenvolvimento Funcional. Resultados: Há preocupação de prejuízo no desenvolvimento atual e futuro da Pessoa/criança, definida como frágil em razão do nascimento prematuro (dimensão Tempo), minimizada pelo alcance de competências observáveis, como habilidades motoras. O Contexto, especialmente família e serviços de saúde, e os Processos proximais, descritos por interações unidirecionais dos cuidadores, são considerados determinantes do desenvolvimento. O desenvolvimento 
funcional é considerado consequência natural e resultado do ensino. A rede de suporte é crucial, apoiando ou limitando o cuidado. Conclusão: Preocupações com o desenvolvimento mobilizam os cuidadores a estimular a Pessoa/criança prematura e demandar suporte familiar e assistencial.

\section{DESCRITORES}

Desenvolvimento Infantil; Prematuro; Cuidadores; Família; Enfermagem Pediátrica.

\section{RESUMEN}

Objetivo: Comprender las concepciones de cuidadores de nacidos prematuros acerca del desarrollo infantil y los factores asociados. Método: Estudio exploratorio descriptivo, cualitativo, con 12 familias de menores de tres años de edad. Entrevistas sometidas al análisis temático de contenido, sistematizadas en las categorías de la Teoría Bioecológica del Desarrollo Humano: Proceso, Persona, Contexto y Tiempo, y la categoría Desarrollo Funcional. Resultados: Existe preocupación de perjuicio en el desarrollo actual y futuro de la Persona/ niño, definido como frágil en virtud del nacimiento prematuro (dimensión Tiempo), minimizada por el alcance de competencias observables, como habilidades motoras. El Contexto, especialmente familia y servicios de salud, y los Procesos proximales, descritos por interacciones unidireccionales de los cuidadores se consideran determinantes del desarrollo. Se considera el desarrollo funcional como consecuencia natural y resultado de la enseñanza. La red de soporte es crucial, al apoyar o limitar el cuidado. Conclusión: Preocupaciones por el desarrollo movilizan a los cuidadores a estimular a la Persona/niño prematuro y demandar soporte familiar y asistencial.

\section{DESCRIPTORES}

Desarrollo Infantil; Prematuro; Cuidadores; Familia; Enfermería Pediátrica.

\section{REFERENCES}

1. Araújo ATC, Eickmann SH, Coutinho SB. Fatores associados ao atraso do desenvolvimento motor de crianças prematuras internadas em unidade de neonatologia. Rev Bras Saúde Matern Infant. 2013;13(2):119-28.

2. Ferreira S, Fontes N, Rodrigues L, Gonçalves C, Lopes MM, Rodrigues N. Desenvolvimento psicomotor de grandes prematuros. Acta Pediatr Port. 2013; 44(6):319-24.

3. Arnold C, Tyson JE. Outcomes following periviable birth. Semin Neonatol. 2014;38(1):2-11.

4. Sullivan MC, Msall ME. Functional performance of preterm children at age 4. J Pediatr Nurs. 2007;22(4):297-309.

5. Potharst ES, Schuenge C, Last BF, van Wassenaer AG, Kok JH, Houtzager BA. Difference in mother-child interaction between preterm and term-born preschoolers with and without disabilities. Acta Paediatr. 2012;101(6):597-603.

6. Costa SAF, Ribeiro CA, Borba RIH, Balieiro MMFG. A experiência da família ao interagir com o recém-nascido prematuro no domicílio. Esc Anna Nery Rev Enferm. 2009;13(4):741-49.

7. Lemos RA, Frônio JS, Neves LAT, Ribeiro LC. Estudo da prevalência de morbidades e complicações neonatais segundo o peso ao nascimento e a idade gestacional em lactentes de um serviço de follow-up. Rev APS. 2010;13(3):277-90.

8. Silva CA, Brusamarello S, Cardoso FGC, Adamczyk NF, Rosa Neto F. Desenvolvimento de prematuros com baixo peso ao nascer nos primeiros dois anos de vida. Rev Paul Pediatr. 2011;29(3):328-35.

9. Lemos RA, Fronio JS, Ribeiro LC, Demarchi R, Silva J, Neves LAT. Functional performance according to gestational age and birth weight of preschool children born premature or with low weight. Rev Bras Cresc Desenvolv Human. 2012;22(1):17-26.

10. Moreira RS, Magalhães LC, Alves CRL. Effect of preterm birth on motor development, behavior, andschool performance of school-age children: a systematic review. J Pediatr (Rio J). 2014;90(2):119-34.

11. Johnson S, Fawke J, Hennessy E, Rowell V, Thomas S, Wolke D, et al. Neurodevelopmental disability through 11 years of age in children born before 26 weeks of gestation. Pediatrics. 2009;124:e249-57.

12. Lemola S. Long-term outcomes of very preterm birth: mechanisms and interventions. Eur Psychol. 2015;20(2):128-37.

13. Melo EMOP, Ferreira PL, Lima RAG, Mello DF. The involvement of parents in the health care provided to hospitalzed children. Rev Latino Am Enfermagem. 2014; 22(3):432-9.

14. Bronfrenbrenner U. Bioecologia do desenvolvimento humano: tornando os seres humanos mais humanos. Porto Alegre: Artmed; 2011.

15. Benetti IC, Vieira ML, Crepaldi MA, Schneider DR. Fundamentos da teoria bioecológica de Urie Bronfenbrenner. Pensando Psicol. 2013;9(16):89-99.

16. Rosa EM, Tudge J. Urie Bronfenbrenner's Theory of Human Development: its evolution from ecology to bioecology. J Fam Theory Rev. 2013;5(4)243-58.

17. Associação Brasileira de Empresas de Pesquisa. Critério padrão de classificação econômica Brasil - 2008 [Internet]. São Paulo: ABEP; 2012 [citado 2012 set. 25]. Disponível em: http://cmicro.fgv.br/sites/cmicro.fgv.br/files/file/CCEB\%20FGV\%20(25-6-2012).pdf

18. Caregnato RCA, Mutti R. Pesquisa qualitativa: análise de discurso versus análise de conteúdo. Texto Contexto Enferm. 2006;15(4):679-84.

19. Mondim EMC. Um olhar ecológico da família sobre o desenvolvimento humano. Psicol Argumento. 2005;23(41):25-35.

20. Andrade AS, Santos DN, Bastos AC, Pedromônico MRM, Almeida-Filho N, Barreto ML. Ambiente familiar e desenvolvimento cognitivo infantil: uma abordagem epidemiológica. Rev Saúde Pública. 2005;39(4):606-11.

21. Pilz EML, Schermann LB. Determinantes biológicos e ambientais no desenvolvimento neuropsicomotor em uma amostra de crianças de Canoas/RS. Ciên Saúde Coletiva. 2007;12(1):181-90. 
22. Brasil. Ministério da Saúde; Secretaria de Atenção à Saúde, Departamento de Ações Programáticas e Estratégicas. Atenção à saúde do recém-nascido: guia para os profissionais de saúde. Brasília; 2011.

23. American Academy of Pediatrics. Follow-up care of high-risk infants. Pediatrics. 2004;114 Suppl 5:1377-97.

24. Souza NL, Pinheiro-Fernandes AC, Clara-Costa IC, Cruz-Enders B, Carvalho JBL, Silva MLC. Domestic maternal experience with preterm newborn children. Rev Salud Pública. 2010; 12 (3):356-67.

25. Custódio ZAO, Crepaldi MA, Linhares MBM. Redes sociais de apoio no contexto da prematuridade: perspectiva do modelo bioecológico do desenvolvimento humano. Estudos Psicol. 2014;31(2):247-55. 